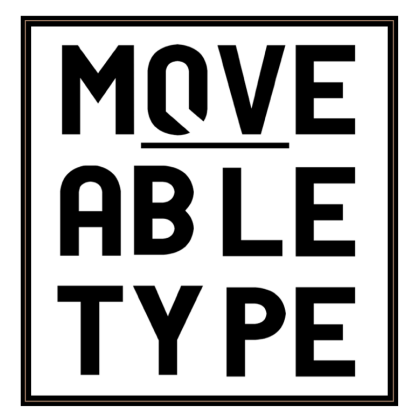

'Crystal Springs Reservoir'

Author: Scott Stevens

Source: Moveable Type, Vol.13, 'Ambience' (2021)

DOI: $10.14324 / 111.1755-4527.127$

MoveableType is a Graduate, Peer-Reviewed Journal based in the Department of English at UCL.

(C) 2021 Scott Stevens. This is an Open Access article distributed under the terms of the Creative Commons Attribution License (CC-BY) 4.ohttps://creativecommons.org/licenses/by/4.0/, which permits unrestricted use, distribution, and reproduction in any medium, provided the original author and source are credited. 


\section{Crystal Springs Reservoir}

Gold flashes in the waves. I wonder

if the rumours were right

about the carp who once

ate a man here whole.

My gilded wish to see

something at sunset.

The lake finds itself

tiresome when blue

and emulates the gray fog

sinking over the wooded mountains:

a green eye

between pale lids about to shut.

At the water's edge,

long dead

grasses wait for winter

rains to reinvent them

into daffodils, lilies - maybe they'll split

at the stalks, then out

walks a new life

form, praying 
mantises, still

virginal

in their lime-colored

coats.

More likely

the reservoir will rise

and drown the grass in spring.

On the other side the redwoods vanish

in mist. What pink metal

will dawn make of these waters. 